\title{
An Institutional Theory Approach to Improve Planning for Innovation and Entrepreneurship Ecosystems in Developing Economies
}

\section{Patrick H. Gaughan ${ }^{1}$, Raj G. Javalgi², and Robert B. Young ${ }^{3}$}

${ }^{1}$ Assistant Dean, Global Engagement, Associate Professor, Law, School of Law Akron, The University of Akron, $\mathrm{OH}$ 44325-2901

${ }^{2}$ Associate Dean, Strategic Initiatives and Research, Professor, Marketing and International Business, Monte Ahuja College of Business, 2121 Euclid Avenue, BU 415, Cleveland, OH 44115 ${ }^{3}$ Associate Professor, School of Business, Baldwin Wallace University, 275 Eastland Road Berea, $\mathrm{OH} 44017$

\section{Introduction}

Corresponding Author: Patrick H. Gaughan pgaughan@uakron.edu

Received: 10 March 2018 Accepted: 10 April 2018

Published: 2 August 2018

Publishing services provided by Knowledge E

(c) Patrick H. Gaughan et al. This article is distributed under the terms of the Creative Commons Attribution License, which permits unrestricted use and redistribution provided that the original author and source are credited.

Selection and Peer-review under the responsibility of the International Applied Research Symposium Conference Committee.

\section{G OPEN ACCESS}

In the present article, the concept of institutional embeddedness is suggested as a potential supplement to the existing literature on entrepreneurial ecosystems in developing economies. Specifically, the present article postulates that the benefits of a vibrant entrepreneurship ecosystem can be thwarted by the failure of country-level institutions to constructively 'reach down' to embed with local entrepreneurship communities. Given the relative shortages of resources and inherent challenges in developing economies, government initiatives may instead adopt a top-down approach in selecting candidates for receipt of support. This would be a mistake. The government effort to identify and select early-stage winners may divert otherwise available endogenous resources away from the broad development of naturally occurring local entrepreneurial ecosystems. Additionally, a top-down approach may miss opportunities for the coordination of additional resources separately existing at the local level.

For these reasons, the present article suggests that one challenge in the development of entrepreneurship ecosystems in developing economies is successfully embedding national institutions into emergent entrepreneurship ecosystems. In addressing this premise, the article first briefly covers the existing literature on entrepreneurial ecosystems. With this as a backdrop, the article next introduces institutional theory and embeddedness as it relates to entrepreneurial ecosystems within developing economies. During this discussion, it is observed that existing entrepreneurial ecosystems may constitute local institutions in their own right with whom national institutions can integrate. Issues regarding measurement, methodology, discussion and conclusions are left for future research. 


\section{Innovation Ecosystems Literature Review}

Beginning in about 2010, the 'entrepreneurship ecosystem' concept began to receive increasing attention in both popular media and academic researchers. In 2010, Daniel Isenberg wrote "How to Start an Entrepreneurial Revolution" in the Harvard Business Review [1]. In that article, Isenberg provided nine prescriptions for creating an entrepreneurship ecosystem: (1) stop emulating Silicon Valley; (2) shape the Ecosystem around local conditions; (3) engage the private sector from the start; (4) favor 'high potentials'; (5) get a big win on the board; (6) tackle cultural change head on; (7) stress the roots (do not provide easy money); (8) do not over-engineer clusters-help them grow organically; and (9) reform legal, bureaucratic and regulatory frameworks [1].

Applying these prescriptions to developing economies raises a number of serious concerns. Most notably, unlike the US context assumed by Isenberg, developing economies are likely to have a relative shortage of both government- and privatesector resources. With this consideration in mind, prescription number (4)-'favor "high potentials"'-could inherently conflict with prescriptions (2) and (8)-developing ecosystems around local conditions and permitting the organic growth of clusters. Given the extremely narrow range of organic opportunities for 'high potentials' in developing economies, governments could be expected to prioritize their allocation of resources to individuals already connected with, or recognized by, the national level. The effective result would be an unwise 'top-down' perspective rather than broad-based support for local organic growth.

One year after his first article, Isenberg proposed a slightly refined 'Entrepreneurship Ecosystem Strategy' that consisted of 'Domains of the Entrepreneurship Ecosystem'. These domains were policy, finance, culture, supports, human capital and markets $[2,3]$. However, this second article remained consistent in stressing the concept of entrepreneurial ecosystems as reflecting 'the world as it impinges on the entrepreneur's perceptions'. The underlying perspective was inherently focused on bottom-up linkages.

A year later, Brad Feld published 'Startup Communities: Building and Entrepreneurial Ecosystem in Your City' [4]. The impact of these efforts 'popularized the idea amongst entrepreneurial leaders and policymakers that a place's community and culture can have a significant impact on the entrepreneurship process' [5]. However, although the general concept of entrepreneurship ecosystem established a wide-spread intuitive appeal, it lacked theoretical clarity. Today, it still does. 
Even today, it is unclear exactly what types of entrepreneurial behavior actually qualify for inclusion within the 'entrepreneurial ecosystems' field. Some scholars limit the term to 'high-growth' or innovation-intensive start-ups [6]. Others include 'networks of innovative start-ups or entrepreneurial employees' as part of entrepreneurial ecosystems [5]. More importantly, there is scarce clarification as to any differences determined by whether the context is within a developed or developing economy. The development concepts have done little to provide practical advice for developing economies to achieve the comparative benefits of having a strong 'entrepreneurship ecosystem' [7-10]. Better guidance is still lacking. However, some insight is suggested by looking to institutional theory and the concept of embeddedness.

\section{Institutional Theory and Embeddedness}

As noted by Peng, Wang and Jiang in 2008, most literature on international business strategy rely upon either the market-based (industry) view or resource-based view. However, both approaches largely ignore 'the formal and informal institutional underpinning that provides the context of competition among industries and firms... In other words, they assume institutions as "background"' [11]. Moreover, it is clear that 'formal and informal institutions, commonly known as the "rules of the game" significantly shape the strategy and performance of firms - both domestic and foreign...' [11, p. 921]. However, the relationship between formal institutions (often originating at the national level) and informal/cultural institutions (often originating at a local or cultural level) is often left to chance.

As noted by Anh and York, the 'institutional differences between developing and developed economies' necessitates going beyond 'resource-based and industry-based models of competition... [and requires] the "institution-based view" of national and global completion' $[12$, p. 260; 13; 11]. In much the same way, endogenous growth theory highlights that regional economic development can be successful by utilizing 'internal forces':

While these forces include a wide array of factors some of the more important are learning, leadership, institutions, physical infrastructure and human capital. Through these it is possible for endogenous closed economic systems with feedback to become self-sustaining and experience the phenomenon of dynamically increasing returns ([14, p. 18]; other citations omitted). 
In this way, the potential value to be achieved by proper deployment of institutions in developing markets is significant. In fact, entrepreneurship ecosystems can actually be viewed as potentially constituting their own unique form of local institution. Extending this perspective, the challenge for developing economies is to determine how the deployment of national institutions (and resources) can best support the development of one or more local entrepreneurship ecosystem institutions. Once again, what is less obvious is how, exactly, this is best achieved.

Although several existing articles have identified the potential role of institutional theory in international business, far fewer have 'drilled down' into institutional theory to provide a more detailed analysis to assist decision makers in developing countries. There is little disagreement that 'institutions matter'; however, questions remain as to exactly 'how' they matter [11, p. 921].

For instance, one area of institutional theory that has yet to closely examine developing economies is the role of 'fields'. According to the institutional theory, as independent entities coalesce into a field, individual organizational perspectives and activities tend to align with the collective group. As aptly stated by DiMaggio and Powell:

Once disparate organizations in the same line of business are structured into an actual field (as ... by competition, the state, or the professions), powerful forces emerge that lead them to become more similar to one another [15].

In this regard, a 'field' is a set of individuals or 'organizations that, in the aggregate, constitute an area of institutional life: key suppliers, resource and product consumers, regulatory agencies, and other organizations that produce similar services or products' [15]. However, given the common lack of infrastructure in many developing markets, the formation of fields often exhibits local and cultural nuances. The efficiency and/or success of national initiatives may sometimes be determined by local, cultural, informal institutional considerations. In further explaining the meaning of 'field', Greenwood, Suddaby and Hinings clarified as follows:

Essential to this definition [of 'field'] is the focus upon 'sets' or 'communities' of [individuals or] organizations that directly interact with one another or are influenced by each other in a meaningful way. (citations omitted).

It is for this reason, that the 'field' within institutional theory integrates seamlessly with the recent efforts to define the relational aspects of entrepreneurial ecosystems [8].

Similarly, the deeper integration of institutional theoretical concepts may further the understanding of 'entrepreneur ecosystems' within the developing countries. 
One of the fundamental challenges for decision makers in developing countries is to understand the individual fields - the local environment for potential entrepreneurship ecosystems-and the needs that are most likely to result in the optimal creation of wealth for a given region. This can be nicely understood within the context of relational aspects of entrepreneurial ecosystems. In this way, the work of scholars like Isenberg [3] and Spigel [8] link directly with the more developed aspects of institutional theory.

In similar fashion, the general concept of 'ecosystems' can also be more deeply incorporated into institutional theory through the concept of 'carrying capacity'. As adopted by institutional theory, environmental 'carrying capacity' is ecologically defined as the sustainable 'number of animals of a given species that can be supported without injury to the habitat' [16]. In this way, within the local and cultural limitations of any particular field, institutional theory would posit that one way to understand 'entrepreneurship ecosystems' is to understand-and consciously manage (or manipulate) the entrepreneurial ecosystem 'carrying capacity'. In order to do this, the developing economies need to appreciate the specific characteristics of the field as interacting with both the 'top-down' national institutions and the 'bottom-up' informal and local/cultural institutions.

'Institutions in their broadest definition are social rule structures with associated standing patterns of behavior and procedures' $[14$, p. 18]. As such, it is understandable how national institutions (often with control over resources, infrastructure and capital) can potentially impact local institutions-like entrepreneurship ecosystems. What might be less obvious-but equally important-is the contribution that local institutions may be able to make to shared projects. Specifically, the voluntary cooperation and alignment of local efforts can have a significant benefit in the form of efficiency. This efficiency can take the form of improved knowledge, talent identification, know-how and even capital $[14$, p. 20$]$.

Importantly, therefore, the perspective of institutional theory and embeddedness is consistent with existing efforts on entrepreneur ecosystems. Most notably, deeper use of institutional theory would suggest that developing economies should make a special effort to establish meaningful local linkages in pursuing ecosystem growth.

\section{Conclusion}

Given the unique challenges of developing economies, it may be understood why initiatives to foster indigenous entrepreneurship ecosystems might adopt a top-down 
approach in selecting candidates for receipt of support. However, adopting an institutional perspective suggests that this would be a mistake. The top-down approach would certainly undermine shaping ecosystems around local conditions. The top-down approach would also fail to help the ecosystems to grow organically. The top-down approach would certainly risk diversion of national resources away from emergent entrepreneurial ecosystems. Perhaps more importantly, a top-down approach would undermine the potential contribution and efficiencies available by focusing on building and integrating with local institutions-the emergent entrepreneurial ecosystems.

\section{References}

[1] Isenberg, D. J. (2010). How to start and entrepreneurial revolution. Harvard Business Review, vol. 88, no. 6, pp. 41-50.

[2] Isenberg, D. J (2011a). The entrepreneurship ecosystem strategy as a new paradigm for economic policy: Principles for cultivating entrepreneurship. The Babson Entrepreneurship Ecosystem Project.

[3] Isenberg, D. J. (2011). Introducing the entrepreneurship ecosystem: Four defining characteristics, Forbes. Retrieved from https://www.forbes.com/sites/ danisenberg/2011/05/25/introducing-the-entrepreneurship-ecosystem-fourdefining-characteristics/\#25afbo455fe8

[4] Feld, B. (2012). Startup Communities: Building and Entrepreneurial Ecosystem in Your City. New York, NY: Wiley.

[5] Stam, E. C. and Spigel, B. (2016). Entrepreneurial ecosystems. USE Discussion Paper Series (16-13).

[6] Mason, C. and Brown, R. (2013). Creating good public policy to support high-growth firms. Small Business Economics, vol. 40, no. 2, pp. 211-225.

[7] Fritsch, M. (2013). New business formation and regional development-A survey and assessment of the evidence. Foundations and Trends in Entrepreneurship, vol. 9, pp. 249-264.

[8] Spigel, B. (2015). The relational organization of entrepreneurial ecosystems. Entrepreneurship Theory and Practice. DOI:10.1111/etap.12167

[9] Tsvetkova, A. (2015). Innovation, entrepreneurship, and metropolitan economic performance: Empirical test of recent theoretical propositions. Economic Development Quarterly, vol. 29, no. 4, pp. 299-316.

[10] Mack, E. and Mayer, H. (2016). The evolutionary dynamics of entrepreneurial ecosystems. Urban Studies, vol. 53, no. 10, pp. 2118-2133. 
[11] Peng, M., Wang, D.Y., and Jiang, Y. (2008). An institution-based view of international business strategy: A focus on emerging economies. Journal of International Business Studies, vol. 39, no. 5, pp. 920-936.

[12] Anh, M. and York, A. (2009). Resource- and institution-based approaches to biotechnology industry development in Malaysia. Asia Pacific Journal of Management, vol. 28, no. 2, pp. 257-275.

[13] Peng, M., Sun, S. L., Pinkham, B., et al. (2009). The institution-based view as a third leg for a strategy tripod. Academy of Management Perspectives, vol. 23, no. 3, pp. 63-81.

[14] Stough, R. R. (2001). Endogenous growth theory and the role of institutions in regional economic development, in B. Johansson, C. Karlsson, R. R. Stough (eds.) Theories of Endogenous Regional Growth-Advances in Spatial Science. Berlin, Heidelberg: Springer.

[15] DiMaggio, P. and Powell, W. W. (1983). The iron cage revisited: Collective rationality and institutional isomorphism in organizational fields. American Sociological Review, vol. 48, no. 2, pp. 147-160.

[16] Barrett, G. W. and Odum, E. P. (2000). The twenty-first century: The world at carrying capacity. Bioscience, vol. 50, no. 4, pp. 363-368.

[17] Cantwell, J., Dunning, J. H., and Lundan, S. M. (2010). An evolutionary approach to understanding international business activity: The co-evolution of MNEs and the institutional environment. Journal of International Business Studies, vol. 41, no. 4, pp. 567-586.

[18] Carney, M., Gedajlovic, E., and Yang, X. (2009). Varieties of Asian capitalism: Toward an institutional theory of Asian enterprise. Asia Pacific Journal of Management, vol. 26, pp. $361-380$

[19] Chadee, D. and Roxas, B. (2013). Institutional environment, innovation capacity, and firm performance in Russia, Critical Perspectives on International Business, vol. 9, no. (1/2), Pp. 19-39.

[20] Chakrabarty, S. and Bass, A. E. (2013). Encouraging entrepreneurship: Microfinance, knowledge support, and the costs of operating in institutional voids. Thunderbird International Business Review, vol. 55, no. 5, pp. 545-562.

[21] Dodgson, M. (2009). Asia's national innovation systems: Institutional adaptability and rigidity in the fact of global innovation challenges. Asia Pacific Journal of Management, vol. 26, no. 3, pp. 589-609.

[22] Drucker, P. (1985). Innovation and Entrepreneurship. New York, NY: Harper Collins. 
[23] Freeman, C. (1987). Technology and Economic Performance: Lessons from Japan. London: Pinter.

[24] Furman, J. L., Porter, M. E., and Stern, S. (2002). The determinants of national innovative capacity. Research Policy, vol. 31, no. 6, pp. 899-933.

[25] Kim, H. and Song, J. (2017). Filling institutional voids in emerging economies: The impact of capital market development and business groups on M\&A deal abandonment. Journal of International Business Studies, vol. 48, no. 3, pp. 308-323.

[26] Liou, R. S., Chao, M. C. H., and Yang, M. (2016). Emerging economies and institutional quality: Assessing the differential effects of institutional distances on ownership strategy. Journal of World Business, vol. 51, no. 4, pp. 600-611.

[27] Lu, Y., Tsang, E., and Peng, M. (2008). Knowledge management and innovation strategy in the Asia Pacific: Toward and institution-based view. Asia Pacific Journal of Management, vol. 25, pp. 361-374.

[28] Minh, T. T., Friederichsen, R., Neef, A., et al. (2014). Niche action and system harmonization for institutional change: Prospects for demand-driven agricultural extension in Vietnam. Journal of Rural Studies, vol. 36, pp. 273-284.

[29] Nelson, R. (1993). National Innovation Systems. A Comparative Analysis. New York, NY: Oxford University Press.

[30] North, D. (1992). Institutions and economic theory. American Economist, vol. 36, no. 1, pp. 3-7.

[31] North, D. (2005). Understanding the Process of Economic Change. Princeton, NJ: Princeton University Press.

[32] Porter, M. E. (1990, republished 1998). The Competitive Advantage of Nations. New York, NY: Free Press.

[33] Puffer, S. and McCarthy, D. (2011). Two decades of Russian business and management research: an institutional theory perspective. Academy of Management Perspectives, vol. 25, no. 2, pp. 21-36.

[34] Ritchie, B. K. (2009). Economic upgrading in a state-coordinated, liberal market economy. Asia Pacific Journal of Management, vol. 26, p. 435.

[35] Scott, W. Richard (2001). Institutions and Organizations (2nd edition). Thousand Oaks: SAGE Publications.

[36] Tipton, F. B. (2009). Southeast Asian capitalism: History, institutions, states and firms. Asia Pacific Journal of Management, vol. 26, no. 3, pp. 401-434.

[37] Venard, B. (2008). Organizational isomorphism and corruption in financial institutions: Empirical research in emerging countries. Journal of Business Ethics, vol. 81, no. 2, pp. 481-498. 
[38] Young, M. N., Tsai, T., Wang, X., et al. (2014). Strategy in emerging economies and the theory of the firm. Asia Pacific Journal of Management, vol. 31, no. 2, pp. 331-354. 